\title{
The Measurement of Subsurface Environment at Cibubur Region West Java Province
}

\author{
Sutrisno $^{a^{*}, \text { Siti Mutia }}{ }^{b}$ \\ ${ }^{\text {a,b }}$ Program Studi Fisika Fakultas Sains dan Teknologi, UIN Syarif Hidayatullah Jakarta \\ Jalan Ir. H. Juanda No.95, Ciputat, Jakarta Indonesia 15412 \\ *E-mail: sutrisno@uinjkt.ac.id
}

\begin{abstract}
It has investigated the subsurface environment on the area of Cibubur Region, West Java Province by using the geoelectric method. This research aims to identify the type of rock layers and ground water based on resistivity values then determine the depth and thickness of aquifers in the study area. This research was conducted using the method of resistivity sounding consisting of five track and measurement configurations using Schlumberger configuration with each path length of $140 \mathrm{~m}$ and $10 \mathrm{~m}$ spacing between tracks. The results obtained from this research that subsurface at every track location of the research has 7 layers of rock that dominated the ground silt containing sand that has resistivity values ranging from $61.48 \Omega \mathrm{m}-113.16 \Omega \mathrm{m}$ bedrock filled with dry soil which has a resistivity value of $316.84 \Omega \mathrm{m}-449.10 \Omega \mathrm{m}$, soil damp soft silt that has a value of resistivity $9.30-13.48$ $\Omega \mathrm{m}$ and bekekar rocks that have resistivity value of 227.26 - $254.04 \Omega \mathrm{m}$. The existence of the aquifer in the study sites are located on each track and are at a depth of $\pm 20 \mathrm{~m}$ to the deepest $\pm 70 \mathrm{~m}$ with a thickness as $50 \mathrm{~m}$ which has resistivity values ranging from $20.21 \Omega \mathrm{m}-81.6 \Omega \mathrm{m}$. This shows that the location of the study had sufficient layer of soil can store water and groundwater passed pretty well.
\end{abstract}

Keywords: Geoelectric method, Resistivity, Aquifer, Schlumberger Configuration, Subsurface environment

\section{Introduction}

The water we use everyday has undergone a meteoric cycle, which is through the process of precipitation of the sea, lake, and river, then condensate in the atmosphere, and then into rain that descends to the surface of the earth. Rain water that descends to the surface of the earth there is a direct flow on the surface of the earth (run off) and there are seeping down the earth's surface (infiltration). Water that flows directly on the surface of the earth is flowing into the river, partly flowing into the lake, and finally back to the sea. Meanwhile, water that seeps below the earth's surface through two systems, namely vadous water system and saturated water system. The saturated water system is underground water contained in a groundwater basin. This system is influenced by geological, hydrogeological, and tectonic forces, and the earth structure that forms the groundwater basin. This water can be stored and flowing in the rock layers that we know with aquifers [1].

\subsection{Geoelectric Resistivity}

The geoelectric method of resistivity or type resistance is one of a group of geoelectric methods used to study the subsurface by studying the nature of the electric current within the rock beneath the earth's surface. Resistivity methods are used for shallow exploration, ranging $300-500 \mathrm{~m}$ depth because only this method that match for this depth. The principle in this method is that the electric current is injected into the earth via two current electrodes, while the potential difference occurring is measured through two potential electrodes. From the result of current measurement and electric potential difference can be obtained variation of resistivity price ofelectricity at layer below the point of measure [1].

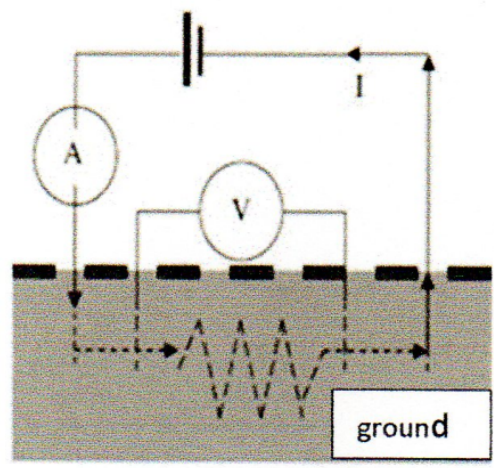

Figure 1.The pattern of current injection.

The electrical resistivity method is performed by injecting the low-frequency electrical current into the earth's surface and then measuring the potential difference between two potential electrodes. I certain circumstances, the subsurface measurement with a fixed current will be obtained a variation of voltage difference which will result in variations in resistance which will bring information about the structure and material it passes. This principle is similar to assuming that the earth's material has a resistive or resistor-like behavior, in which the materials have different degrees in conducting electrical current [2].

Based on the purpose of investigation this method is divided into two namely mapping and sounding. Mapping resistivity method is a resistivity method that aims to study horizontal subsurface resistivity variation. While the sound resistivity method aims to study the variations of rock resistivity beneath the earth's surface vertically. In this method, the measurement at a sounding point is done by changing the distance of the electrode. This electrode distance change is not done arbitrarily, but starting from a small electrode spacing then gradually enlarges. The distance of this electrode is proportional to the depth of the rock layer detected. From the depth of the rock layer detected, the thickness and resistivity of each layer of rock will be obtained [2]. 


\subsection{Electrode Configuration}

Electrode configuration is often used in the sounding technique that is Schlumberger configuration.

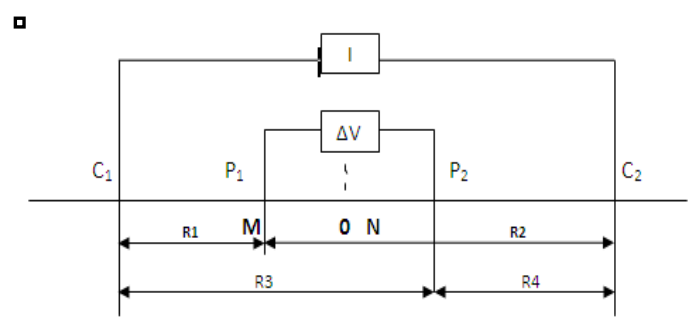

Figure 2. Schlumberger Configuration.

The advantage of the schlumberger configuration is the ability to detect the non-homogeneous nature of the rock layers on the surface comparing the apparent resistivity value when there is a change in the distance of the MN / 2 electrode. The measured parameters are: distance between stations with electrodes ( $\mathrm{AB} / 2$ and $\mathrm{MN} / 2$ ), current (I), and potential difference $(\Delta \mathrm{V})$. The calculated parameters are: resistance type $(\mathrm{R})$ and geometric factor $\mathrm{k}[3]$.

\subsection{Akuifer}

Aquifers are underground layers that contain water and are able to drain water. This is because the layer is permeable that is able to drain the water either because of the pores in the layer or indeed the nature of a particular rock layer.

\subsection{Type of Aquifer}

1. Confined aquifer (aquifer) is an aquifer whose upper and lower layers are bounded by a watertight layer.

2. A semi-confined aquifer is an aquifer whose layers above or below are still capable of passing through water even though very small (slow).

3. Semi-free aquifer (semi unconfined aquifer). This type of aquifer is a shift between a distressed half aquifer with a non-suppressed (free) aquifer. Where, the bottom layer is a waterproof layer, while the top layer is fine-grained material, so that the cover layer still allows the movement of water.

4. Aquifer free (unconfined aquifer). In this type of aquifer the upper layer has a high permeability, so the air pressure in the water surface is equal to the atmosphere. Groundwater from this aquifer is called free groundwater (not depressed) and the aquifer itself is often called a water-table aquifer[3].

\section{Methodology}

In this chapter describes the research starting from the data acquisition stage (acquisition) to get the data ready to be processed using Progress software to know the subsurface subsection and IP2Win software to know the subsurface layer. The data processing phase begins by performing the data processing first in Microsoft excel to find the value of $\mathrm{K}$ and $\mathrm{r}$, once obtained will be inserted into the IP2Win software to know its subsurface sections, and to find out the subsurface layers inserted into the Progress software[5].
In the data analysis used software Progress and IP2Win software to speed up and simplify the process of data processing. Data processing is aimed at obtaining resistivity values on each rock layer and identifying subsurface layers.

\section{Result and Discussion}

Results from data processing using Progress software and IP2Win software can be seen in Path 1, Path 2, Path 3, Path 4 and Path 5

\subsection{Trajectory Interpretation 1 using Progress}

In track 1 there are 5 types of rock / soil. The first begins with layers 1 and 3 which have Rock / soil. In layers 1 and 3 having a resistivity value of $61.48 \Omega \mathrm{m}-61.75 \Omega \mathrm{m}$ at depths of $0 \mathrm{~m}-0.1 \mathrm{~m}$ and $5 \mathrm{~m}-27 \mathrm{~m}$ composed of silt sandite soil. Then in layer 2 at depth $0.1 \mathrm{~m}-5 \mathrm{~m}$ which has a value of resistance type $242.20 \Omega \mathrm{m}$ is composed of bedrock kekar filled with moist soil. In layer 4 is composed of silt soil and soft soaked soft soil that has a type of resistance of $9.30 \Omega \mathrm{m}$ at a depth of $27 \mathrm{~m}-47 \mathrm{~m}$. While in layers 5 and 6 which have a resistance value type $18.05 \Omega \mathrm{m}$ and $47.28 \Omega \mathrm{m}$ at a depth of $47 \mathrm{~m}-70 \mathrm{~m}$ a resistance value of type ranging of $18.05 \Omega \mathrm{m}$ dan $47.28 \Omega \mathrm{m}$ at depth $47 \mathrm{~m}-$ $70 \mathrm{~m}$ a resistance value of type ranging from $75.40 \Omega \mathrm{m}$ $81.52 \Omega \mathrm{m}$ at depths of $0 \mathrm{~m}-0.1 \mathrm{~m}$ and $2 \mathrm{~m}-25 \mathrm{~m}$ [5].

This coating is made up of silt, sandy soil. The second in layer 2 depth of $0.1 \mathrm{~m}-2 \mathrm{~m}$ has a value of $449.10 \Omega \mathrm{m}$ resistivity composed of bedrock filled with dry soil. Then the third in layer 4 has a resistance value type $13.48 \Omega \mathrm{m}$ at a depth of $25 \mathrm{~m}-41 \mathrm{~m}$ which is composed of silt soil and soil wet soft soil. While in layers 5 and 6 dikedalaman $41 \mathrm{~m}$ - $70 \mathrm{~m}$ which has a resistance value of $20.21 \Omega \mathrm{m}-49.81$ $\Omega \mathrm{m}$ is composed of fresh water. The last one at a depth of $\geq$ $70 \mathrm{~m}$ that has a $99.56 \Omega \mathrm{m}$ resistance value is arranged Of clay. The existence of aquifer on track 1 is expected to be depth $41 \mathrm{~m}-70 \mathrm{~m}$ with thickness $29 \mathrm{~m}$ [5].

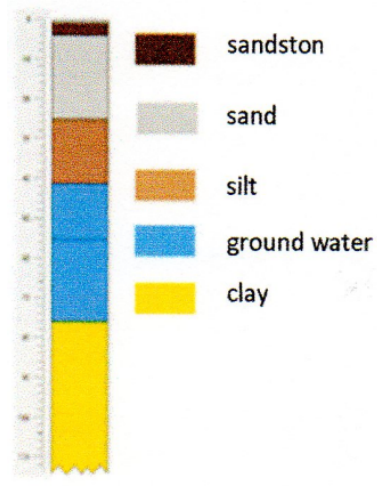

Figure 3. Resistivity Log on Track 1.

Table 1. Interpretation ofTrack 1

\begin{tabular}{|l|c|c|l|}
\hline$d(\mathrm{~m})$ & $\mathrm{h}(\mathrm{m})$ & $\rho(\Omega \mathrm{m})$ & material \\
\hline $0-0.1$ & 0.1 & 75.40 & sand \\
\hline $0.1-2$ & 1.9 & 449.10 & sandstone \\
\hline $2-25$ & 25 & $\$ 1.52$ & sand \\
\hline $25-41$ & 16 & 13.48 & silt \\
\hline $41-56$ & 15 & 20.21 & ground water \\
\hline $36-70$ & 14 & 49.81 & ground water \\
\hline$>70$ & 2 & 99.56 & clay \\
\hline
\end{tabular}


According to the geological arrangement and the price of water graduation, groundwater on track 1 can be called groundwater or depressed middle soifies that the above or below layers are still capable of passing through water even though very small (slow).

\subsection{Trajectory Interpretation 2 Using Progress}

In track 2 there are 5 types composed of fresh water. In layer 7 which has a resistance value of $94.20 \Omega \mathrm{m}$ type with a depth of $\geq 70 \mathrm{~m}$ is composed of clay. The existence of aquifer on track 2 is found at a depth of $47 \mathrm{~m}-70 \mathrm{~m}$ with a thickness of $23 \mathrm{~m}$.

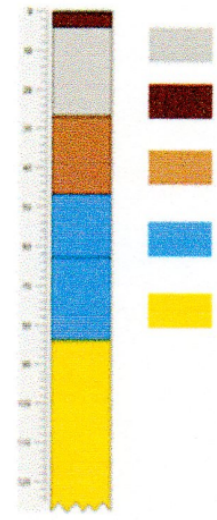

sand

limestone

silt

round water

clay

Figure 4. Log resistivity of track 2

Table 2. Interpretation of track 2

\begin{tabular}{|l|c|c|l|}
\hline$d(m)$ & $h(m)$ & $\rho(\Omega \Omega)$ & material \\
\hline $0-0.1$ & 0.1 & 61.48 & sand \\
\hline $0.1-5$ & 4.9 & 242.40 & limestone \\
\hline $5-27$ & 22 & 61.75 & sand \\
\hline $27-47$ & 20 & 9.30 & silt \\
\hline $47-63$ & 14 & 18.05 & ground water \\
\hline $63-70$ & 7 & 47.28 & ground water \\
\hline$>70$ & $\sim$ & 94.20 & clay \\
\hline
\end{tabular}

According to the geological arrangement and the price of water graduation, groundwater in layer 2 can be called groundwater or a semi free aquifer between the aquifer half-suppressed and the aquifer is not depressed (free). Where, the bottom layer is a waterproof layer, while the top layer is fine-grained material, so that the cover layer still allows the movement of water [6].

\subsection{Trajectory Interpretation 3 Using Progress}

In track 3 there are 4 types of rock / soil. In layers 1,3 and 4 which have a resistance value of $17.04 \mu \mathrm{m}$ and 87.78 $\Omega \mathrm{m}-104.33 \Omega \mathrm{m}$ at depths of $0 \mathrm{~m}-0.1 \mathrm{~m}$ and $3 \mathrm{~m}-22 \mathrm{~m}$ are composed of silt sandite soils. Then in layer 2 with a depth of $0.1 \mathrm{~m}-3 \mathrm{~m}$ which has a resistance value type $344.47 \Omega \mathrm{m}$ is composed of bedrock filled with dry soil. In layers 5 and 6 which have a resistance value of type 28.30 $\Omega \mathrm{m}-57.45 \Omega \mathrm{m}$ with a depth of $22 \mathrm{~m}-53 \mathrm{~m}$ is composed of fresh water. And at layer 7 with a depth of $53 \mathrm{~m}-70 \mathrm{~m}$ which has a resistance value of type $109.46 \Omega \mathrm{m}$ is composed of limestone. The existence of aquifer in trajectory 3 is suspectedat a depth of $22 \mathrm{~m}-53 \mathrm{~m}$ with a thickness of $31 \mathrm{~m}[6]$.

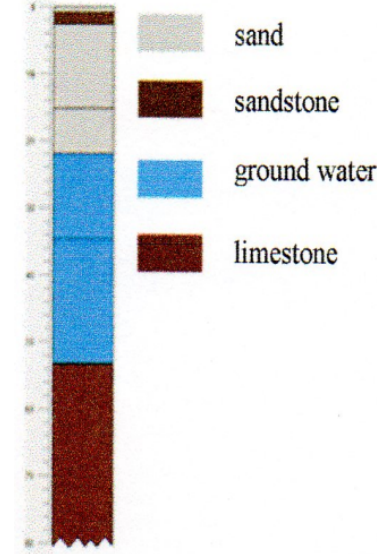

Figure 5. Log resistivity track 3

Table 3. Interpretation of track 3

\begin{tabular}{|c|c|c|l|}
\hline$d(\mathrm{~m})$ & $\mathrm{b}(\mathrm{m})$ & $\rho(\mathrm{gm})$ & Material \\
\hline $0-0.1$ & 0.1 & 104.33 & sand \\
\hline $0.1-3$ & 2.9 & 344.47 & sandstone \\
\hline $3-15$ & 12 & 87.78 & sand \\
\hline $15-22$ & 7 & 17.04 & sand \\
\hline $22-34$ & 12 & 28.30 & ground wat \\
\hline $34-53$ & 19 & 57.45 & ground water \\
\hline $53-70$ & 17 & 109.46 & limestone \\
\hline
\end{tabular}

According to the geological arrangement and the graduation of water, groundwater on track 3 is called groundwater or aquitard aquifer, which is a permable geological formation with a small hydraulic conductivity value but still allows water to pass through this layer even with slow motion. So this aquitard can be called as waterproof layer. It can also be said to be the upper and lower limiting layer of a semi confined aquifer [7].

\subsection{Trajectory Interpretation 4 Using Progress}

In track 4 there are 5 types of rock / soil. The first in layers 1 and 4 with a depth of $0 \mathrm{~m}-0.01 \mathrm{~m}$ and $7 \mathrm{~m}-20 \mathrm{~m}$ which has a resistance value of $75.96 \mu \mathrm{m}$ and $113.16 \mu \mathrm{m}$ is made up of silt sandite soil. The second in layer 2 which has a resistance value type $316.84 \Omega \mathrm{m}$ at a depth of $0.01 \mathrm{~m}$ - $3 \mathrm{~m}$ allegedly composed of bedrock filled with dry soil. The third is thought to be composed of basalt rocked with moist soil that has a resistance value type 166.61 with a depth of $3 \mathrm{~m}-7 \mathrm{~m}$. At a depth of $20 \mathrm{~m}-55 \mathrm{~m}$ allegedly composed of fresh water that has a value of resistance type ranges from $23.58 \Omega \mathrm{m}-46.22 \Omega \mathrm{m}$. And the last one in layer 7 which has a resistance value of $94.46 \Omega \mathrm{m}$ type with a depth of $55 \mathrm{~m}-\geq 70 \mathrm{~m}$ is composed of clay. The existence of aquifer in path 4 is found at depth of $20 \mathrm{~m}-55$ $\mathrm{m}$ with thickness of $35 \mathrm{~m}[7]$. 


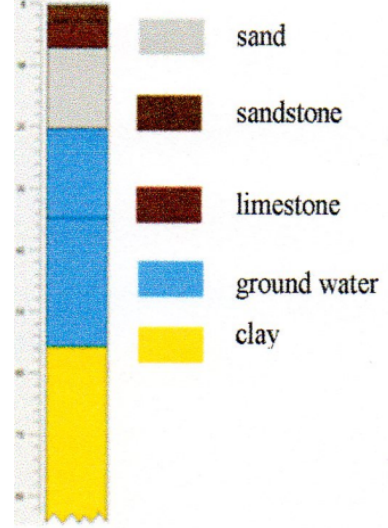

Figure 6. Log resistivity track 4

Table 4. Tabel interpretation of track 4

\begin{tabular}{|l|c|c|l|}
\hline$d(m)$ & $b(m)$ & $\rho(\Omega \mathrm{m})$ & material \\
\hline $0-0.1$ & 0.1 & 61.48 & sand \\
\hline $0.1-5$ & 4.9 & 242.40 & limestone \\
\hline $5-27$ & 22 & 61.75 & sand \\
\hline $27-47$ & 20 & 9.30 & silt \\
\hline $47-63$ & 14 & 18.05 & ground water \\
\hline $63-70$ & 7 & 47.28 & ground water \\
\hline$>70$ & 2 & 94.20 & clay \\
\hline
\end{tabular}

According to the geological arrangement and the graduation of water, groundwater on track 4 can be called groundwater or semi-suppressed aquifer, semi-impermeable geological formation, capable of draining water but at a very slow rate. it may be capable of carrying large quantities of water between the aquifers with each other. This half-depressed aquifer is also known as aquitard[7]

\subsection{Trajectory Interpretation 5 Using Progress}

In track 5 there are 4 types of rock / soil. In layers 1 and 2 which have a resistance value type $227.26 \Omega \mathrm{m}$ $254.04 \Omega \mathrm{m}$ with a depth of $0 \mathrm{~m}-5 \mathrm{~m}$ which is composed of bedrock flower filled with soft soil. Then in layer 3 it is composed of silt sandite soil having a resistivity value of $102.68 \Omega \mathrm{m}$ at a depth of $5 \mathrm{~m}-7 \mathrm{~m}$. In layers 4 and 5 allegedly composed of fresh water at a depth of $17 \mathrm{~m}-55$ $\mathrm{m}$ which has a resistance value of type ranged from 20.51 $\Omega \mathrm{m}-57.08 \Omega \mathrm{m}$. While layer 6 with a depth of $55 \mathrm{~m}-70 \mathrm{~m}$ which has a resistance value type 10.07 is composed of silt soil and soil wet soft soil. And in layer 7 is composed of silt soil that has a resistance value of type $100.24 \Omega \mathrm{m}$ with a depth of $\geq 70 \mathrm{~m}$. The presence of aquifers in layer 5 is suspected to be at depth of $17 \mathrm{~m}-55 \mathrm{~m}$ with thickness of $36 \mathrm{~m}[8]$.

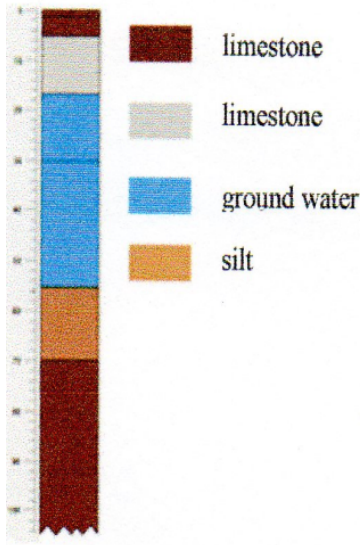

Figure 7. Log resistivity of track 5

Table 5. Interpretation of track 5

\begin{tabular}{|c|c|c|l|}
\hline$d(m)$ & $h(m)$ & $\rho(\Omega m)$ & Material \\
\hline $0-1$ & 1 & 227.26 & limestone \\
\hline $1-5$ & 4 & 254.04 & limestone \\
\hline $5-17$ & 12 & 102.68 & sand \\
\hline $17-30$ & 13 & 57.08 & ground water \\
\hline $30-55$ & 25 & 20.51 & ground water \\
\hline $55-70$ & 15 & 10.07 & silt \\
\hline 370 & 2 & 100.24 & limestone \\
\hline
\end{tabular}

According to the geological arrangement and the graduation of water, groundwater on track 5 can be called groundwater or semi-free aquifers, namely the aquifer which is entirely saturated water, where the upper part is bounded by a semi-pass water layer and below is an impermeable layer[9].

\section{Result of correlation from Path 1 - 5 by Using Progress}

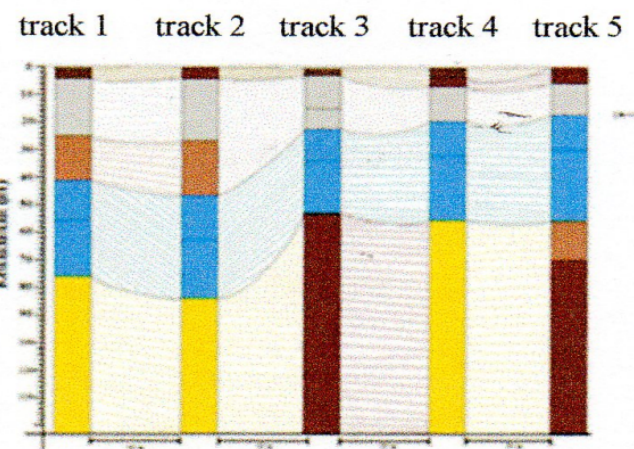

Figure 8. Corelation of track $1-5$

\section{Interpretation of Tracks 1 - 5 using IP2Win}

The results of each layer are almost not very different from the results of the identification of the progress software that identifies the subsurface. The existence of the aquifer is located in all trajectories and is present at any depth ranging from $20 \mathrm{~m}-\geq 70 \mathrm{~m}$ with a thickness of $50 \mathrm{~m}$ with a resistivity value of $23.6 \Omega \mathrm{m}-81.6 \Omega \mathrm{m}[10]$. 


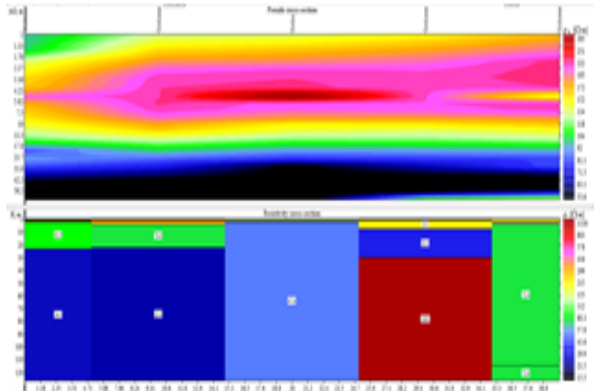

Figure 9. Processing IP2Win track 1-5

Overall results from Progress and IP2Win prove a clear picture of the existence of aquifers at the study site. From the software progress aquifer can be detected at a depth of $20 \mathrm{~m} \mathrm{-} \geq 70 \mathrm{~m}$ because in each trajectory the depth has a small resistivity value of $20.21 \Omega \mathrm{m}-57.45 \Omega \mathrm{m}$ which has a suspected silt soil type containing sand, which means that the depth of the aquifer[11].

Then the result of IP2Win software is not much different from Progress software, because the existence of aquifer is in depth $20 \mathrm{~m}-\geq 70 \mathrm{~m}$ which is shown with green and blue color image with thickness $50 \mathrm{~m}$ with resistivity value 23.6 $\Omega \mathrm{m}-81.6 \Omega \mathrm{m}[12]$.

\section{Conclusion}

1. The surface layer on each track of the research area is generally dominated by a silt soil layer containing sand, dry ground bedrock, wet soft soil and rocky rocks. This indicates that the location of the research has a layer that can store and pass the groundwater well enough.

2. The location of the study has a good enough aquifer potential characterized by the discovery of aquifer layer at a depth of about $20 \mathrm{~m}$ to the deepest found at depths of about $\geq 70 \mathrm{~m}$ which has a thickness of $50 \mathrm{~m}$. The results of this study were obtained by comparing two different software ie Progress and IP2Win software.

\section{References}

[1] Ashari, B. et al,

PemetaanPenyebaranPolaAkuiferdenganMetodeResistivitas Sounding Konfigurasi Schlumberger di Daerah DayuGondangrejoKaranganyar. Indonesian Journal of Applied Physics (2014) Vol.04 No.1.

[2] Kurniawan Alva. 2009. Tutorial IP2WIN. Yogyakarta.

[3] Muharis, C. et al. 2010. PendugaankarakteristikakuiferdengankonfigurasiSchlumber ger di Parupuktabing Padang. PoliteknikNegeri Padang. Jurnal. RekayasaSipil Volume VI, Nomor 2, Oktober 2010. Halaman $106-112$.

[4] Pranata, J. 2015. Identifikasi Keberadaan Akuifer dengan Metode Geolistrik Konfigurasi Schlumberger di Buperta.Skripsi. UIN SyarifHidayatullah Jakarta.

[5] Rolia, E. PenggunaanMetodeGeolistrikUntukMendeteksiKeberadaan Air Tanah.Jurnal. TAPAK Vol. 1 No. 1 Nopember 2011. Halaman $1-10$

[6] Rozaq, A. et al. 2013. Identifikasikedalamandanstrukturlapisanbawahtanahcandij ajaghuberdasarkannilairesistivitasdenganmenggunakameto degeolistrikkonfigurasi Dipole - dipole. Jurnal. Physics Student Journal. Vol 1. No 1. 2013. Halaman 1-5.
[7] Susilo, A. 2012. Pendugaanakuifersertapolaalirannyadenganmetoegeolistrik daerahpondokpesantrengontor 11 solok. Sumatera Barat. Physics Student Journal. Vol 2. No 1. 2014. Halaman $1-5$.

[8] http://tukangbata.blogspot.com/2013/02/pengertian-akuiferatau-aquifer-html. 31 Mei 2016 Pukul 19.34 WIB.

[9] https://www.academia.edu/4531032/AKUIFER. 1 Juni 2016pukul19.00 WIB

[10] http://www.academia.edu/geofisikametodegeolistrik 6 Juni 2016 pukul 20.17 WIB.

[11] https://trisusantosetiawan.wordpress.com/2011/metodegeolistrik-resistivitas. 16 Juni 2016 Pukul 22.25 WIB.

[12] http://dhayatgeo.blogspot.com/2011/identifikasi-air-tanahmelalui-teknik 19 Juni 2016 Pukul 21.07 WIB. 